\title{
What do we live from? An overview of the first comprehensive Hungarian house- hold wealth survey*
}

\section{Béla Simon}

Head of Department

Central Bank of Hungary

E-mail: simonb@mnb.hu

Ádám Valentiny
Statistical Analyst
Central Bank of Hungary
E-mail: valentinya@mnb.hu
While the assessment of income inequalities dates back to several decades, the generation of information, and analyses on the structure and distribution of households' wealth have started recently. In the second half of the 2000s, the ECB (European Central Bank) initiated the launch of a standardised, comprehensive survey on household finance and consumption covering the entire euro area (HFCS - Household Finance and Consumption Survey $)^{1}$, the first wave of which was conducted in EU member states in 2010 and 2011. The first wave involved interviews with over 62000 households across fifteen countries, and the survey results were made available from 2013. The second wave already covered twenty countries, including Hungary, involving interviews with 84000 households, conducted in most countries in 2014. The third wave of the survey is currently underway, as part of which fieldwork was carried out in member states in 2017. This overview aims to explain the contents and possible uses of the HFCS, position the Hungarian survey in the international field, and report on survey results.

\section{KEYWORDS:}

Household finances.

Wealth.

Financial assets.

DOI: 10.20311/stat2017.K21.en029

\footnotetext{
* On behalf of the MNB (Magyar Nemzeti Bank - the Central Bank of Hungary), Gábor Huszár and Mihály Szoboszlai contributed to the preparations for the Hungarian survey and the evaluation of the results.

${ }^{1}$ The methodology of the survey is designed, and its conduct is coordinated by the Household Finance and Consumption Network, an international working group of researchers and statisticians, established in 2006. The Governing Council of the ECB decided on the launch of the survey series at the end of 2008. The survey is conducted every three years, using a standardised questionnaire. The Hungarian survey was named "What do we live from?"
} 
In the United States, surveys on household finances have been conducted every three years since the 1980s. ${ }^{2}$ The aggregate results are within close range of macrostatistics, which provides particularly sound foundations for the combined use of micro- and macro information, and for an investigation of how household indicators are structured at the level of the national economy, and distributed within the sector. Regular surveys have been launched in several countries across Europe on households' wealth, financial savings, sources of finance, and debt; for example, Finland, Italy, France, the Netherlands, Spain and Portugal had already conducted their own finance surveys before the joint European data collection. Implemented using a standardised methodology and questionnaire, the creation of the European survey was motivated by these American and European examples as well as by increasing data needs in the aftermath of the financial crisis in the late 2000s. The countries previously conducting similar household surveys either joined the survey coordinated by the ECB (European Central Bank), or integrated the additional questions in the single European questionnaire into their own existing data collection efforts.

\section{Structure and general characteristics of the household survey}

The implementation of the European HFCS (Household Finance and Consumption Survey) at the national level is a responsibility of central banks or the entities appointed by them. Within the questionnaire, the ECB has designated core questions, providing the option to omit certain questions or include them using different specifications, and to add country-specific questions to the questionnaire. Naturally, there is also a possibility for member states to retrieve certain income, consumption and savings data included in the survey from available administrative data sources, authority's records or statistical registers, so that they do not need to be collected directly from households. ${ }^{3}$ The national entities are also responsible for selecting the sample of respondents and the interview method for the survey, and for processing, adjusting and weighting up the results, by taking the recommendations of the Household Finance and Consumption Network into account. Given the fundamental re-

\footnotetext{
${ }^{2}$ Survey on Consumer Finances, Federal Reserve System.

${ }^{3}$ To date, extensive use of register data instead of interviews has only been made by Finland.
} 
quirement that the survey should also be representative at the national level, each participating country must provide for an adequate sample size. The concentration of financial wealth and of specific instruments particularly justified widespread interviews, which may also be facilitated by oversampling more wealthy strata. Member states may decide whether to conduct the three-year surveys on a constant or a partially constant sample (panel). The ECB collects anonymised data from participating countries, which it releases in publications on methodology and analysis reports following verification and aggregation. Additionally, it makes the full database of each wave of the survey available for further analysis and research.

The European HFCS comprises three major structural parts. The first, introductory part records general information and information on residence, identifies the persons in the household, and designates the household reference person, who is preferably the head of the household, or the highest earner, that is the most knowledgeable about the household's finances. The second part of the survey includes questions on income and assets, savings, and consumption expenditures. Arranged into nine topics and to be answered partly at the level of the individual and partly at the level of the household, these questions constitute the essential part of the survey. In the third and final part of the survey, the interviewer applies a set of predefined criteria to evaluate the interview completed. Such feedback on the success, quality and circumstances of the interview provides important information on the usability of the questionnaires completed, which the statistical entities take into account for their decisions on accepting, adjusting or completing the responses received from household members.

Of the nine topics covered by the central part of the survey, three (Demography; Employment; Pensions and insurance policies) include personal questions concerning individual household members, and five (Real assets and their financing; Other liabilities and credit constraints; Private businesses and financial assets; Intergeneration transfers and gifts; Consumption) concern the household as a whole. Questions on income include questions at both the personal and the household level.

A novel feature of the survey is the comprehensive description of households' financial and non-financial assets and liabilities, and the aligning of these assets with traditional demographic, income and consumption issues within a questionnaire. Not only does this enable the distribution of individual instruments among households to be examined on the basis of questionnaires, but it also allows the complete household account to be compiled in a simplified form, and the known macroeconomic relationships between income, consumption and accumulation processes to be explored in greater depth. All this enables a far more comprehensive analysis of social inequalities than previously. 


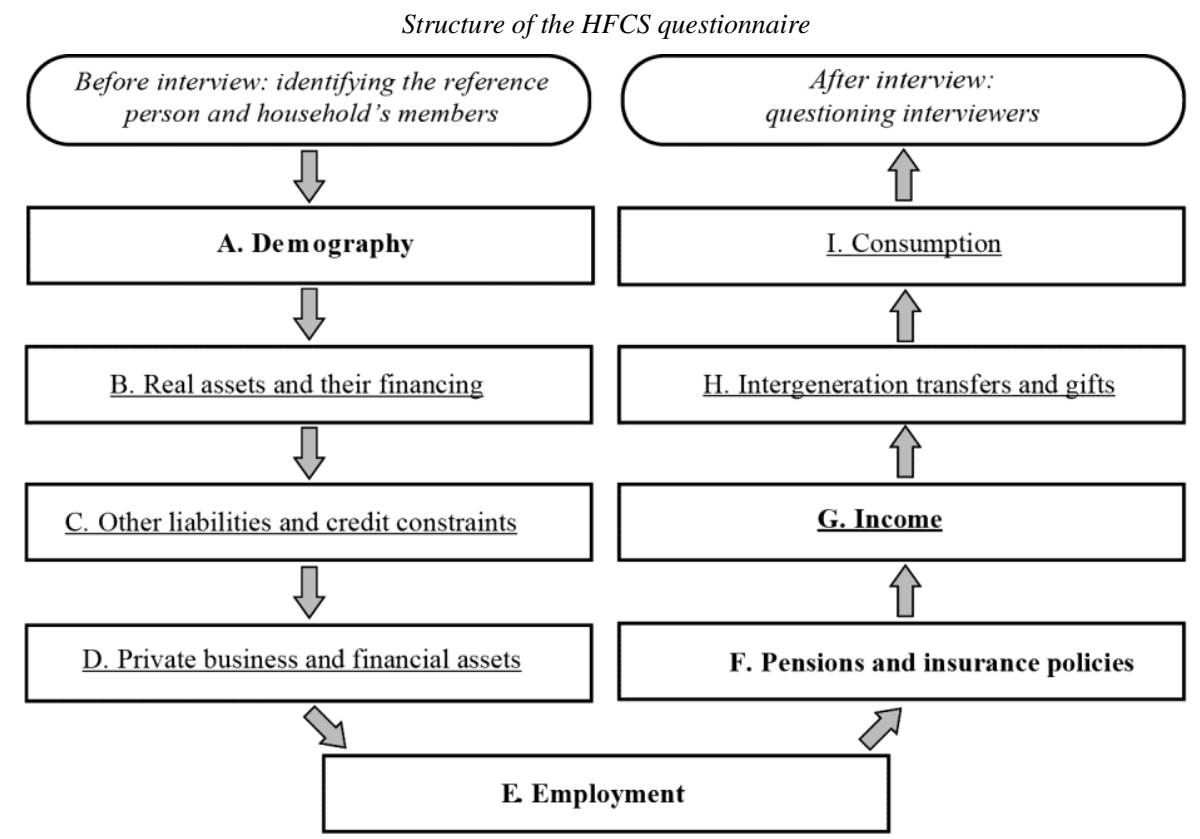

Note. The topics typed in bold cover questions of personal level, while topics underlined refer to questions of household level.

Source: EUROPEAN CENTRAL BANK [2013]: The Eurosystem Household Finance and Consumption Survey - Methodological Report for the First Wave. Statistics Paper Series. No. 1. April. https://www.ecb.europa.eu/ pub/pdf/other/ecbsp1en.pdf?c5295916d8521d593c30abc97ef9fc58

\section{Experiences from the second wave of the survey outside Hungary}

The second wave of the HFCS covered 18 euro area members as well as Poland and Hungary, with field work carried out mostly in 2014 or $2015 .{ }^{4}$ Interviews generally took three to eleven months to conduct. In most participating countries, stock (wealth) data were asked as at the time of the interview, whereas flow (income and consumption) data were asked for the previous calendar year. The survey covered private households resident in the country concerned, generally excluding residents of institutionalised households (prisons, institutions, care homes), and the homeless. In some countries, additional limitations were also applied in the course of sample selection. Consequently, the weighted up population from the survey tends to be $1-3 \%$ lower than the actual resident population.

\footnotetext{
${ }^{4}$ Except for Estonia (2013), Ireland (2013), Portugal (2013), and Spain (2012).
} 
Gross and net sample sizes in the first and second waves of the HFCS

(number of households)

\begin{tabular}{|c|c|c|c|c|c|}
\hline \multirow{2}{*}{ Country } & \multicolumn{2}{|c|}{ First wave } & \multicolumn{2}{|c|}{ Second wave } & \multirow{2}{*}{$\begin{array}{c}\text { Difference } \\
{[(\mathrm{d} / \mathrm{b} * 100)-100]} \\
(\%)\end{array}$} \\
\hline & $\begin{array}{l}\text { Gross sample size } \\
\text { (a) }\end{array}$ & $\begin{array}{l}\text { Net sample size } \\
\text { (b) }\end{array}$ & $\begin{array}{c}\text { Gross sample size } \\
\text { (c) }\end{array}$ & $\begin{array}{l}\text { Net sample size } \\
\text { (d) }\end{array}$ & \\
\hline Austria & 4436 & 2380 & 6308 & 2997 & 26 \\
\hline Belgium & 11376 & 2364 & 7265 & 2238 & -5 \\
\hline Cyprus & 3938 & 1237 & 1874 & 1289 & 4 \\
\hline Estonia & - & - & 3594 & 2220 & - \\
\hline Finland & 13525 & 10989 & 13960 & 11030 & 0 \\
\hline France & 24289 & 15006 & 20272 & 12035 & -20 \\
\hline Greece & 6354 & 2971 & 7368 & 3003 & 1 \\
\hline Netherlands & 2263 & 1301 & 2562 & 1284 & -1 \\
\hline Ireland & - & - & 10522 & 5419 & - \\
\hline Poland & - & - & 7000 & 3483 & - \\
\hline Latvia & - & - & 2405 & 1202 & - \\
\hline Luxembourg & 5000 & 950 & 7300 & 1601 & 69 \\
\hline Hungary & - & - & 17985 & 6207 & - \\
\hline Malta & 3000 & 843 & 2035 & 999 & 19 \\
\hline Germany & 20501 & 3565 & 16221 & 4461 & 25 \\
\hline Italy & 15592 & 7951 & 16100 & 8156 & 3 \\
\hline Portugal & 8000 & 4404 & 8000 & 6207 & 41 \\
\hline Spain & 11782 & 6197 & 13442 & 6106 & -1 \\
\hline Slovakia & 2000 & 2057 & 4202 & 2136 & 4 \\
\hline Slovenia & 965 & 343 & 6519 & 2553 & 644 \\
\hline Total & 133021 & 62558 & 174934 & 84626 & 35 \\
\hline
\end{tabular}

Source: EuROPEAN CENTRAL BANK [2016a]: The Household Finance and Consumption Survey - Methodological Report for the Second Wave. Statistics Paper Series. No. 17. December. https://www.ecb.europa.eu/pub/ pdf/scpsps/ecbsp17.en.pdf

EUROPEAN CENTRAL BANK [2016b]: The Household Finance and Consumption Survey - Results from the Second Wave. Statistics Paper Series. No. 18. December. https://www.ecb.europa.eu/pub/pdf/scpsps/ ecbsp18.en.pdf?d2911394a25c444cd8d3db4b77e8891a

In the second wave of the survey series, interviews were successfully completed with more than 84000 households, with response rates between $20 \%$ and $65 \%$ across countries. In order to reach more wealthy households and to observe various assets more thoroughly, oversampling was applied on a regional basis in six countries and based on indicators of income, assets or consumption in ten countries, while in four 
countries no efforts were made to oversampling the wealthy households. ${ }^{5}$ Three countries already implemented the first common survey as part of a panel, and another four countries indicated their intention to do so in the second wave. ${ }^{6}$ In the majority of participating countries, households' responses were recorded exclusively by means of CAPI (computer-assisted personal interviewing). Of the twenty participating countries, the exceptions were Finland, the Netherlands and Poland. Finland relied exclusively on CATI (computer-assisted telephone interviewing), the Netherlands used CAWI (computer-assisted web interviewing), and Poland opted for PAPI (paper-and-pencil interviewing). The questionnaire typically took 40 to 70 minutes per household to complete. In Estonia, Finland, France, Hungary, Ireland, Latvia, Poland, Portugal and Slovakia, the survey was conducted by the national statistical offices, while in the rest of the countries the central banks engaged third-party companies and research institutes for the administration of the questionnaire. However, additional work on the survey was carried out, i.e. the data were adjusted, completed and weighted up by the central bank, or the central bank in cooperation with the institution conducting the interviews.

The data quality of the European HFCS varies greatly by country. Overall, coverage of the turnover data and real assets also included in other surveys and authority's databases exceeds $80 \%$, and $40-90 \%$ of known national economy figures on various forms of credit are also represented in the aggregates of the survey. By contrast, the survey typically managed to observe only $20-50 \%$ of the value of financial assets, based on adjusted and weighted up data. ${ }^{7}$ The shortcomings encountered in the coverage of financial assets are attributable to differences between the definitions of households and instruments only to a limited extent, the real causes were nonresponse and the exclusion of the wealthiest households from the survey.

Results from the second wave of the survey have appeared in various publications since 2016. This was also the year in which the ECB published its methodological report on the survey ${ }^{8}$, and its summary paper on HFCS results ${ }^{9}$. In 2013, the OECD

\footnotetext{
${ }^{5}$ Adjustments for the distorting effect of oversampling is made in the course of weighting by applying a lower weight to households that were over-represented in the sample.

${ }^{6}$ Eventually, the survey was conducted on a panel in Belgium, Cyprus, Finland, Germany, Italy, Malta, the Netherlands and Spain.

${ }^{7}$ In certain countries, the number of imputed items could be up to $50 \%$ of the values of the variables concerned. In contrast with income and consumption data, micro-data from other surveys are not available on financial wealth, as a result of which these variables could only be adjusted from within the questionnaire, preserving their original characteristics (averages, ranges, and distributions).

${ }^{8}$ EUROPEAN CENTRAL BANK [2016a]: The Household Finance and Consumption Survey - Methodological Report for the Second Wave. Statistics Paper Series. No. 17. December. https://www.ecb.europa.eu/pub/pdf/ scpsps/ecbsp17.en.pdf

${ }^{9}$ EUROPEAN CENTRAL BANK [2016b]: The Household Finance and Consumption Survey - Results from the Second Wave. Statistics Paper Series. No. 18. December. https://www.ecb.europa.eu/pub/pdf/scpsps/ ecbsp18.en.pdf?d2911394a25c444cd8d3db4b77e8891a
} 
also released its methodological guidelines ${ }^{10}$, then in summer 2015 it published its household wealth database ${ }^{11}$ compiled using the data available from eleven countries in Europe and seven outside Europe, which it also used as the basis of several studies.

\section{General characteristics of the Hungarian household survey}

Together with Estonia, Ireland, Poland and Latvia, Hungary joined the European HFCS in the second wave, and like most countries, it interviewed the selected households in 2014. The notional date of the survey was 30 September 2014, and interviews were conducted between 20 October and 23 November in 187 selected settlements. The survey was carried out by the Hungarian Central Statistical Office on behalf of the $\mathrm{MNB}$, and the results were evaluated as part of cooperation between the two institutions. Large even in an international comparison, a sample of 18000 households was selected $^{12}$, of which an interview was successfully completed in 6207 households, representing a $34.6 \%$ completion ratio. ${ }^{13}$ The wealthiest households were oversampled on a regional basis, with households from settlements in Budapest and Pest county oversampled relative to their proportions. The interviewers visited all selected addresses in person, and residents had the option to respond to the questions either as part of personal interviews (assisted by surveyors), or through the internet (by self-reporting). Most respondents chose to respond through the internet in Budapest and in Pest and Somogy counties, where the overall response rates were the lowest. ${ }^{14}$

Due to the large sample and oversampling, responses were collected successfully from over 1000 households in Budapest and approximately 540 in Pest County. Large self-representing settlements accounted for two-thirds of respondent households. In addition to being representative nationally, the survey also adequately reflects house-

\footnotetext{
${ }^{10}$ ORGANISATION FOR ECONOMIC CO-OPERATION AND DEVELOPMENT [2013]: OECD Guidelines for Micro Statistics on Household Wealth. OECD Publishing. http://dx.doi.org/10.1787/9789264194878-en

${ }^{11}$ OECD Wealth Distribution Database (https://stats.oecd.org/Index.aspx?DataSetCode=WEALTH).

${ }^{12}$ In the second wave, only France had a larger gross sample. The actual completion ratios were only higher in Finland, France and Italy.

${ }^{13}$ An interview is considered to have been completed successfully when all required questions have been answered, which account for about one-half of the more than 200 questions, and mostly comprise yes/no questions. Questions about amount values are generally not required, and the questionnaire concerned may be completed successfully even if such questions have the "Don't know" or "No answer" options marked. These missing data must be completed subsequently in the course of data processing.

${ }^{14}$ The possibility of self-reporting through the internet increased the willingness to respond, whereby completion of the questionnaires was also undertaken by households that would deny entry to interviewers, or would decline a personal interview. However, in such cases the third part of the survey, consisting of the surveyor's quality report and feedback on the soundness of the responses, is missing.
} 
holds' main demographical, income and consumption characteristics. At the end of 2014, Hungary had a resident population of 9856000 with 4180000 households, while the corresponding figures weighted up from the survey were 9697000 and 4128000 , respectively. The differences $(-1.6 \%$ and $-1.2 \%$, respectively) are negligible and are comparable to those observed in other countries. In the 6207 respondent households, a total of 14623 persons were surveyed, of whom 12313 were over the age of 16. For each person in the latter group, a specific personal questionnaire was completed on marital status, education, economic activity, employment and income. At the MNB's request, an extra question was inserted into the questionnaire on how the persons concerned received their wages (in cash or to their bank accounts).

Table 2

Completion ratios in Hungary by county (net to gross sample sizes)

\begin{tabular}{l|c|c}
\hline \multirow{2}{*}{\multicolumn{1}{c|}{ County }} & Total completion & Of which: internet \\
\cline { 2 - 3 } & \multicolumn{2}{|c}{$(\%)$} \\
\hline Budapest & 19.3 & 57.8 \\
\hline Bács-Kiskun & 40.8 & 21.2 \\
\hline Baranya & 43.9 & 11.6 \\
\hline Békés & 50.7 & 25.3 \\
\hline Borsod-Abaúj-Zemplén & 41.0 & 26.2 \\
\hline Csongrád & 34.7 & 22.8 \\
\hline Fejér & 43.2 & 30.3 \\
\hline Győr-Moson-Sopron & 36.8 & 30.8 \\
\hline Hajdú-Bihar & 42.9 & 23.1 \\
\hline Heves & 51.9 & 20.8 \\
\hline Jász-Nagykun-Szolnok & 45.6 & 24.2 \\
\hline Komárom-Esztergom & 35.1 & 23.4 \\
\hline Nógrád & 52.4 & 28.1 \\
\hline Pest & 32.9 & 38.5 \\
\hline Somogy & 31.7 & 37.2 \\
\hline Szabolcs-Szatmár-Bereg & 50.6 & 34.5 \\
\hline Tolna & 52.6 & 21.5 \\
\hline Vas & 37.9 & 33.6 \\
\hline Veszprém & 54.1 & 17.2 \\
\hline Zala & 35.1 & 27.9 \\
\hline Country total & 34.6 & 31.4 \\
\hline
\end{tabular}

Source: Own calculations. 


\subsection{Incomes and expenditures of individuals and households in the Hungarian survey}

As regards incomes, the personal questionnaire provides information on the gross amount of incomes from employment and self-employment, pensions and unemployment benefits over the preceding twelve months. ${ }^{15}$

Table 3

\begin{tabular}{|c|c|c|c|c|c|c|}
\hline \multirow[b]{2}{*}{ Description } & \multicolumn{4}{|c|}{ Imputed survey data } & \multicolumn{2}{|c|}{ National economy data* } \\
\hline & $\begin{array}{l}\text { Number } \\
\text { of persons }\end{array}$ & $\begin{array}{l}\text { Weighted } \\
\text { number of } \\
\text { persons }\end{array}$ & $\begin{array}{c}\text { Amount } \\
\text { (billions of } \\
\text { HUF) }\end{array}$ & $\begin{array}{l}\text { Weighted } \\
\text { amount } \\
\text { (billions of } \\
\text { HUF) }\end{array}$ & $\begin{array}{l}\text { Number } \\
\text { of persons }\end{array}$ & $\begin{array}{c}\text { Amount } \\
\text { (billions of } \\
\text { HUF) }\end{array}$ \\
\hline Employee income & 5811 & 4180804 & 12.3 & 8588 & 3370000 & 7143 \\
\hline Self-employment income & 691 & 517050 & 1.1 & 895 & 492000 & 852 \\
\hline Public pension & 4570 & 2491841 & 5.8 & 3142 & 2300000 & 3000 \\
\hline Other pension & 46 & 26715 & 0.0 & 15 & - & - \\
\hline Unemployment benefits & 403 & 320217 & 0.1 & 54 & 450000 & 86 \\
\hline
\end{tabular}

*Data at the national economy level include estimates.

Source: Adjusted data of the Hungarian HFCS.

The completeness and adequate quality of personal income data are of key importance in terms of how the survey is judged as a whole, because it is on such incomes for which the widest range of data are available from other surveys and administrative data sources, and in a number of cases personal income data will be used to estimate the missing values of other variables in the survey. In the course of data processing, income data had to be completed (due to non-response) or adjusted for $17 \%$ of respondents with employee incomes, $30 \%$ of those with self-employment incomes, $7 \%$ of pensioners, and more than $35 \%$ of those receiving unemployment benefits. According to adjusted survey data, completed by means of imputation, over $90 \%$ of the working age population had some personal income in the year preceding the survey. Weighted income values correspond to the national economy totals known from other data sources. (See Table 3.) With personal incomes, therefore, no

15 The Hungarian questionnaire offered the option of stating net incomes, which were then converted into gross amounts in the course of processing. Rather than for the preceding calendar year, incomes and expenditures were to be stated for the year preceding the notional date of the survey, from October 2013 to September 2014. The stock data refer to the end of September 2014. 
distorting effect from non-response or underreported amounts can be demonstrated in comparison with other surveys. ${ }^{16}$

The HFCS household questionnaire collects data on respondents' main residence, other real properties, vehicles, other assets, various credit constraints, selfemployment businesses, other investments, incomes and consumption. The survey therefore only includes household-level questions about assets owned by persons living and doing business together, on the incomes derived from such assets (i.e. rental income from real estate property, business, financial investments), on the various forms of public assistance and private transfers, and on consumption and accumulation expenditures. Incomes and benefits surveyed at the household level complement the incomes observed at the level of the individuals, collectively amounting to private households' incomes observed as part of the survey.

Table 4

\begin{tabular}{l|r|r|r|r}
\multicolumn{1}{c}{ Annual gross data for incomes at the level of households } \\
\multicolumn{1}{c|}{ Description } & $\begin{array}{c}\text { Number } \\
\text { of house- } \\
\text { holds }\end{array}$ & $\begin{array}{c}\text { Weighted number } \\
\text { of households }\end{array}$ & $\begin{array}{c}\text { Amount } \\
\text { (millions } \\
\text { of HUF) }\end{array}$ & $\begin{array}{c}\text { Weighted amount } \\
\text { (millions } \\
\text { of HUF) }\end{array}$ \\
\hline Public assistance or welfare payments & 1627 & 1134043 & 593 & 407482 \\
\hline Cash transfers from persons outside the household & 360 & 242293 & 120 & 80337 \\
\hline Rental income from real estate property & 190 & 127093 & 136 & 88566 \\
\hline Income from financial investments & 3303 & 2181428 & 380 & 248544 \\
\hline Income from other business & 13 & 11911 & 32 & 21371 \\
\hline Income from any other sources & 188 & 137778 & 133 & 78467 \\
\hline
\end{tabular}

Source: Adjusted data of the Hungarian HFCS.

Household-level incomes concern a wide range of households, but their amounts fall short of that of personal incomes. For that reason and in the absence of detailed external information, with the exception of incomes from financial investments, in the course of data processing only minor amount adjustments were made to these income variables, and there was no possibility to review the group of respondents concerned. ${ }^{17}$ Generally, respondent households find it difficult to recognise, identify

${ }^{16}$ The significant need for the completion and adjustment of data on unemployment benefits may have resulted from differences in the interpretation of the questions, as a number of respondents only considered the job seekers' allowance, or the monthly amount of the benefit in completing the questionnaire.

${ }^{17}$ For rental income from real estate property and income from financial investments, outliers were adjusted. In the case of financial investments, the number of households concerned increased from 300 to 3303 because as part of imputation, this type of income was assigned to every household with bank deposits or 
and quantify these household-level incomes, as a result of which the survey could observe only a minor part of public benefits representing a HUF 1000 billion magnitude at the level of the national economy, interest income exceeding HUF 450 billion, annual dividends received in an amount over HUF 560 billion, and on the expenditure side, of property rent estimated at HUF 154 billion. (See Table 4.) The assessment of incomes from insurance or other complex financial investments appears downright impossible as part of such a general survey, and where needed, their value should rather be estimated while making use of the data.

When annual incomes assessed at the personal level are aggregated to the level of households and are combined with household-level observations on incomes, consumption and loan repayments, an understanding is gained of the additional income that households can spend on investments through the purchase of financial or nonfinancial assets. (See Table 5.)

Table 5

\begin{tabular}{l|c|c}
\hline \multicolumn{1}{c|}{ Annual summary data for incomes, consumption expenditures and loan repayments } \\
\hline \multicolumn{1}{c|}{ Description } & $\begin{array}{c}\text { Weighted number } \\
\text { of households }\end{array}$ & $\begin{array}{c}\text { Weighted amount } \\
\text { (billions of HUF) }\end{array}$ \\
\hline Incomes at the level of individuals & 4007239 & 12694 \\
\hline Incomes at the level of households & 2794308 & 925 \\
\hline Consumer expenditures & 4127671 & 6202 \\
\hline Rent of property & 384546 & 154 \\
\hline Expenditures on loan repayments & 1269811 & 920 \\
\hline
\end{tabular}

Source: Adjusted data of the Hungarian HFCS.

Owed to the specificities of the survey, the assessment of consumer expenditures only covers regular spending required for housing and livelihood, excluding amounts spent on the acquisition of assets (e.g. the purchase of household appliances and furniture) and to access various services (e.g. travel, repairs, and renovations). Expenditures on loan repayments are limited to interest expenditures and net principal repayments. ${ }^{18}$ As opposed to incomes, data on consumer expenditures and expenditures on loan repayments were adjusted only slightly in the course of processing survey results. Due to observation deficiencies on the expenditure side, a significant additional income (ex-

securities. An upward adjustment would also have been warranted to incomes from business; however, there is no such clear relationship between investments in private equity and their property incomes as between interestbearing instruments and their interest incomes.

${ }^{18}$ According to macrostatistics, in 2014 households' interest expenditures amounted to HUF 600 billion, and net principal repayments to HUF 340 billion. 
ceeding HUF 6000 billion) is shown for the sector as a whole, whereas the actual amount spent on the accumulation of assets is estimated to have been between HUF 2000 and 3000 billion in $2014 .{ }^{19}$ The absolute value of the additional income (savings) calculated from the survey, therefore, cannot be used directly to estimate the volume of asset accumulation, but could provide a reference for a distinction between households that invest, those in equilibrium, those consume their investments, and those finance excess consumption by borrowing. A judgement in this regard is facilitated by additional household-level questions in the survey concerning the links between incomes and expenditures, the purpose of savings, and the source of excess expenditures. For example, one important finding of the survey could be the fact that in 2014, expenditures exceeded incomes in $13 \%$ of Hungarian households, while $27 \%$ reported excess incomes after the payment of their expenditures. $60 \%$ of the households reported an equilibrium of their incomes and expenditures.

\subsection{Coverage of financial and non-financial wealth in the Hungarian survey}

Essentially, the HFCS has been created for a household-level assessment of the various financial assets held by households, credit constraints, and the non-financial assets whereby these are covered. A fundamental question therefore concerns the extent and standard to which these assets, which previously had not been assessed directly, could be observed, and the extent to which the results of the first wealth survey may be used for a breakdown of sector-level macrostatistics and to describe the distribution of wealth among households. ${ }^{20}$ Contrary to expectations, questions on the holdings and value of various assets and financial assets generally did not result in refusals to participate in the survey; nevertheless, in line with the experience of other countries, with these questions the level of completion and the quality of the answers are definitely lower relative to other parts of the survey.

The part of the household questionnaire assessing financial and non-financial wealth includes questions arranged into four sections designed to capture holdings of various assets and liabilities. First, it collects data on residential property and other real property (number, size, value, year of acquisition), then it assesses the features of related mortgage loans (maturity, interest, initial and outstanding amount, instalment). This is followed by questions on the number of vehicles and other valuables,

\footnotetext{
${ }^{19}$ Based on the national accounts, in 2014 households spent HUF 1600 billion on net purchases of financial assets, and less than HUF 1000 billion on the accumulation of non-financial assets.

${ }^{20}$ In the national accounts, both financial and non-financial assets held by the household sector are recognised on the basis of external information reported by counterpart sectors. Such external information generally concerns the sector as a whole and does not provide access to more in-depth data at the household level.
} 
and on the characteristics of non-mortgage credit constraints by type (overdraft facilities, commodity advances, lease agreements, other credit, private loans).

Table 6

Summary data on real assets, property loans and other credit constraints

\begin{tabular}{l|c|c|c|c}
\hline \multicolumn{1}{c|}{ Description } & $\begin{array}{c}\text { Number of households } \\
\text { concerned in the sample }\end{array}$ & $\begin{array}{c}\text { Weighted number } \\
\text { of households }\end{array}$ & $\begin{array}{c}\text { Amount in the sample } \\
\text { (billions of HUF) }\end{array}$ & $\begin{array}{c}\text { Weighted amount } \\
\text { (billions of HUF) }\end{array}$ \\
\hline Real property & 5627 & 3742814 & 60 & 38510 \\
\hline Vehicles & 3232 & 2100949 & 4 & 2483 \\
\hline Other valuables & 301 & 185649 & 1 & 330 \\
\hline Property loans & 1195 & 832708 & 7 & 1585 \\
\hline Other loans & 1616 & 1132728 & 2 & 4565 \\
\hline
\end{tabular}

Source: Adjusted data of the Hungarian HFCS.

Data on real property and related loans, and on other credit and loans collected as part of the survey have undergone major adjustments and completion. Missing data on the value of properties have been completed on the basis of other characteristics using external data sources, and the various characteristics of property loans have been reconciled with and adjusted for one another as well as the characteristics of the properties. Regarding vehicles and other assets, adjustments have only been made in the case of obvious errors and missing data. According to the national accounts, the national economy value of real property owned by households amounts to HUF 35000 billion, whereas the real property portfolio grossed up from the survey is higher at HUF 39000 billion. Based on macrostatistics, in autumn 2014 private households' credit exceeded HUF 8000 billion, while the survey has produced $75 \%$ of that amount, HUF 6150 billion. The HFCS allows the household-level assessment of circumstances and purposes of borrowing, the characteristics of the loans, the methods and amounts of repayment and loan replacement, and the phenomena of loan avoidance and debt accumulation, while providing a first opportunity to explore the value, scope and characteristics of private lending among households. (Close to 10\% of Hungarian households have such debt, of which every fourth has several such debts.)

The assessment of the value of financial assets held by households, being perhaps the most valuable part of the survey, is comprised of observations on the value of business assets and other financial instruments (funds, securities, loans granted, savings from insurance, and pensions). The section on businesses collects information on the number of businesses operated by each household as well as on their legal form, size, value, number of employees and activities. This section surveys investments in both sole proprietorships and various partnerships; however, to ensure com- 
parability with data in the national accounts, for the purposes of the survey only capital investments in partnerships are considered as households' financial assets, while no distinction is made between sole proprietorships and the private households operating them. ${ }^{21}$ (See Table 7.)

\begin{tabular}{|c|c|c|c|c|c|c|}
\hline \multirow[b]{2}{*}{ Description } & \multicolumn{4}{|c|}{ Imputed survey data } & \multicolumn{2}{|c|}{ National economy data } \\
\hline & $\begin{array}{l}\text { Number of } \\
\text { households } \\
\text { concerned }\end{array}$ & $\begin{array}{c}\text { Weighted } \\
\text { number of } \\
\text { households }\end{array}$ & $\begin{array}{l}\text { Amount in } \\
\text { the sample } \\
\text { (billions of } \\
\text { HUF) }\end{array}$ & $\begin{array}{l}\text { Weighted } \\
\text { amount } \\
\text { (billions of } \\
\text { HUF) }\end{array}$ & $\begin{array}{l}\text { Number of } \\
\text { households }\end{array}$ & $\begin{array}{c}\text { Amount } \\
\text { (billions of } \\
\text { HUF) }\end{array}$ \\
\hline Cash & 6207 & 4127671 & 0.4 & 245 & 4180000 & 2956 \\
\hline Deposits in current accounts & 5003 & 3344131 & 2.6 & 1644 & 3300000 & 2450 \\
\hline Other fixed deposits & 3115 & 2065363 & 5.6 & 3671 & - & 4650 \\
\hline Securities & 496 & 301859 & 3.0 & 1924 & 400000 & 3000 \\
\hline Private loans (assets) & 524 & 392734 & 1.1 & 733 & - & - \\
\hline Shares and equities & 474 & 334948 & 8.2 & 6951 & 450000 & 10768 \\
\hline Investment fund shares & 483 & 309713 & 3.1 & 2041 & 400000 & 3963 \\
\hline Pension- and life insurance & 899 & 633330 & 2.3 & 1615 & - & 3075 \\
\hline
\end{tabular}

Note. Data at the national economy level include estimates.

Source: Adjusted data of the Hungarian HFCS (for imputed survey data) and financial account statistics (for national economy data).

In the Hungarian survey, at the request of the MNB a question on cash held at home was added to the single European questionnaire in the part on financial assets. Also at the request of the Central Bank, in respect of all financial assets and separated from the total, a section to assess the value of foreign financial assets held by households was added to the Hungarian questionnaire. In the course of data processing, adjustments have been made in respect of all financial instruments in terms of both the group of households concerned and asset values. The values missing from the survey have been completed on the basis of consumer expenditures in respect of cash, and on the basis of incomes aggregated at the household level for deposits and various securities. The survey successfully covered more than $50 \%$ of sector-level national

${ }^{21}$ A methodological difference between the sectoral definitions of macrostatistics (national accounts) and the HFCS is that the former consider sole proprietorships as integral parts of the household sector, whereas the scope of the survey only includes private households, which report sole proprietorships as separate business assets. In the national accounts, households' assets and liabilities include those of sole proprietorships, without any recognition of ownership or capital investments. 
economy values for all financial assets observed except for cash, with an average $60 \%$ coverage of financial wealth. With the instrument of shares, equities, and reserves in pensions and life insurance, the significant shortfall compared with the totals known from financial accounts may have partly resulted from difficulties in the evaluation of investments. In the case of cash, the survey generally did not include observations on cash holdings for accumulation. Reported holdings amounting to $8 \%$ of the national economy value are predominantly comprised of small amounts of cash held for transaction purposes. (The largest reported cash holding was HUF 5 million.)

The absence of additional information has prevented statistical bodies from adjusting data on holdings of foreign financial assets, on which specific questions were asked among those concerning the various financial assets owned by households. According to weighted up data, about $5 \%$ of households reported balances of foreign cash in hand or on account worth a total of HUF 190 billion, corresponding to $27 \%$ of the value in macrostatistics. Very few respondents reported wealth of foreign shares, insurance or pensions, with HUF 17, 23, and 11 billion worth of investments, respectively, aggregated from the survey as at autumn 2014.

A fundamental question is how the difference (shortfall) in the processed and grossed up (weighted) data of the survey relative to household macrostatistics is distributed among households. This influences the way in which the information obtained from the questionnaire should be used in breaking down the data on holdings in the household sector and in describing the size of differences in wealth. This simplest and generally applied solution is to project the distribution of various assets calculated from the survey on macrostatistics, as a result of which the distributions among various strata of households will be identical to those obtained from the survey, assuming that the differences affect all segments of the sector proportionally. However, experience shows that non-response and non-participation in the survey are not distributed randomly within the population, but are concentrated in the households with the highest and the lowest incomes.

The illustrative examples in Tables 8-10 show that the different types of financial assets are missing to various degrees in each household stratum. The grossed up results of the survey have a central tendency with each instrument as outliers have not been observed and imputation was also based on average values. At the same time, the degree of centralisation in the survey varies by instrument according to the nature of the instruments, the scope of the data, and the method of reporting and imputation. For cash, the significant difference between the cash holdings surveyed and those derived from the financial accounts is probably explained by the outstanding unobserved cash holdings of the wealthiest households, while the differences in bank deposits and various securities, of a smaller magnitude, are distributed more evenly among household strata, and are not specifically attributable to the wealthiest households. (See Tables 8 and 9.) 
Distribution of households' bank deposits as surveyed, by size

\begin{tabular}{|c|c|c|c|c|c|}
\hline \multirow{3}{*}{ Description } & \multicolumn{4}{|c|}{$\begin{array}{l}\text { Value of current account and other deposits } \\
\text { by category }\end{array}$} & \multirow{3}{*}{ Total } \\
\hline & $0-0.2$ & $0.2-5$ & $5-30$ & $30-$ & \\
\hline & \multicolumn{4}{|c|}{ millions of HUF } & \\
\hline Number of households (national economy, thousands) & 1150 & 1820 & 320 & 10 & 3300 \\
\hline Distribution by size category $(\%)$ & 34.8 & 55.2 & 9.7 & 0.3 & 100.0 \\
\hline Number of households (survey, weighted, thousands) & 1125 & 2038 & 177 & 10 & 3350 \\
\hline Distribution by size category $(\%)$ & 33.6 & 60.8 & 5.3 & 0.3 & 100.0 \\
\hline Value of deposits (national economy, billions of HUF) & 120 & 2700 & 3130 & 1150 & 7100 \\
\hline Distribution by size category $(\%)$ & 1.7 & 38.0 & 44.1 & 16.2 & 100.0 \\
\hline Value of deposits (survey, weighted, billions of HUF) & 73 & 2847 & 1683 & 713 & 5316 \\
\hline Distribution by size category (\%) & 1.4 & 53.5 & 31.7 & 13.4 & 100.0 \\
\hline
\end{tabular}

Note. Data at the national economy level include estimates.

Source: Distribution data have been retrieved from the National Deposit Insurance Fund (OBA).

Table 9

Distribution of debt securities held by households, by size

\begin{tabular}{|c|c|c|c|c|c|}
\hline \multirow{3}{*}{ Description } & \multicolumn{4}{|c|}{$\begin{array}{l}\text { Value of securities per household, by size } \\
\text { category }\end{array}$} & \multirow{3}{*}{ Total } \\
\hline & $0-1$ & $1-6$ & $6-30$ & $30-$ & \\
\hline & \multicolumn{4}{|c|}{ millions of HUF } & \\
\hline Number of households (national economy, thousands) & 126 & 213 & 130 & 13 & 482 \\
\hline Distribution by size category (\%) & 26.1 & 44.2 & 27.0 & 2.7 & 100.0 \\
\hline Number of households (survey, weighted, thousands) & 67 & 110 & 120 & 4 & 301 \\
\hline Distribution by size category $(\%)$ & 22.3 & 36.6 & 39.8 & 1.3 & 100.0 \\
\hline Value of securities (national economy, billions of HUF) & 89 & 696 & 1508 & 707 & 3000 \\
\hline Distribution by size category $(\%)$ & 3.0 & 23.2 & 50.3 & 23.5 & 100.0 \\
\hline Value of securities (survey, weighted, billions of HUF) & 24 & 296 & 1388 & 216 & 1924 \\
\hline Distribution by size category $(\%)$ & 1.3 & 15.4 & 72.1 & 11.2 & 100.0 \\
\hline
\end{tabular}

Note. Data at the national economy level include estimates.

Source: Distribution data have been retrieved from the Investor Protection Fund (BEVA).

Currently, the most accurate data on distribution by investment size are available on investments in corporate shares and equities, which is why the data on equity 
holdings obtained from the Hungarian HFCS enable a more detailed investigation of size distribution relative to other assets. (See Table 10.) The comparison shows that according to corporate data, households exceeding HUF 1 billion account for more than $30 \%$ of the private equity wealth of the sector, whereas the household survey has no observed values in this size category. (The highest reported value of shares and equities is HUF 700 million.) With this instrument, therefore, the difference in the aggregates is predominantly explained by the absence of the highest values.

Table 10

Distribution of household equity in non-publicly traded companies by size

\begin{tabular}{|c|c|c|c|c|c|c|c|}
\hline \multirow{3}{*}{ Description } & \multicolumn{6}{|c|}{ Value of corporate equity by category } & \multirow{3}{*}{ Total } \\
\hline & $0-1$ & $1-5$ & $5-10$ & $10-100$ & $100-1000$ & $1000-$ & \\
\hline & \multicolumn{6}{|c|}{ millions of HUF } & \\
\hline $\begin{array}{l}\text { Number of companies (national } \\
\text { economy) }\end{array}$ & 198032 & 91000 & 33194 & 71082 & 15362 & 1330 & 410000 \\
\hline $\begin{array}{l}\text { Distribution by size category } \\
(\%)\end{array}$ & 48.3 & 22.2 & 8.2 & 17.3 & 3.7 & 0.3 & 100.0 \\
\hline $\begin{array}{l}\text { Number of companies (survey, } \\
\text { weighted) }\end{array}$ & 38200 & 156143 & 86437 & 58356 & 11508 & 0 & 350644 \\
\hline $\begin{array}{l}\text { Distribution by size category } \\
(\%)\end{array}$ & 10.9 & 44.5 & 24.7 & 16.6 & 3.3 & 0.0 & 100.0 \\
\hline $\begin{array}{l}\text { Value of equity (national econo- } \\
\text { my, billions of HUF) }\end{array}$ & 29 & 255 & 244 & 2353 & 4335 & 3399 & 10615 \\
\hline $\begin{array}{l}\text { Distribution by size category } \\
(\%)\end{array}$ & 0.3 & 2.4 & 2.3 & 22.2 & 40.8 & 32.0 & 100.0 \\
\hline $\begin{array}{l}\text { Value of equity (survey, billions } \\
\text { of HUF) }\end{array}$ & 11 & 429 & 584 & 1258 & 3341 & 0 & 5623 \\
\hline $\begin{array}{l}\text { Distribution by size category } \\
(\%)\end{array}$ & 0.2 & 7.6 & 10.4 & 22.4 & 59.4 & 0.0 & 100.0 \\
\hline
\end{tabular}

Source: Own calculations.

\section{Summary}

The first comprehensive household finance survey provides an opportunity to investigate households' incomes, consumption, finances and assets in context. The 
scope and quality of the survey make it suitable for a description of the structure and distribution of household wealth, for which no data source has been available to date. As the survey was conducted as part of the European HFCS initiated by the ECB, it also enables a broad comparative analysis of households' finances and assets. The data show that the first Hungarian survey has been successful even by international standards, as the response rate and the coverage of a range of variables have both been above expectations. With its more than two hundred questions, the survey has provided a rich database for analyses on differences in income and assets, indebtedness, habits of borrowing, saving and investment as well as on a number of broader social and financial developments and phenomena. We trust that by describing this new household survey and by exploring the opportunities it offers for analysis, and its specific limitations, we may contribute to the understanding and broad utilisation of this data asset. In addition to raising awareness, the aim of this overview is to provide a summary on data contents and the methodological background of the survey, which is essential for the proper use of the data asset, and the appropriate interpretation of the results.

\section{Appendix}

\begin{tabular}{|c|c|c|c|c|}
\hline \multirow{2}{*}{ Region/county } & \multicolumn{2}{|c|}{ Person in the household } & \multicolumn{2}{|c|}{ Household } \\
\hline & Respondent & $\begin{array}{l}\text { Respondent } \\
\text { (weighted) }\end{array}$ & Respondent & $\begin{array}{l}\text { Respondent } \\
\text { (weighted) }\end{array}$ \\
\hline Bács-Kiskun & 710 & 394535 & 302 & 175537 \\
\hline Békés & 654 & 349026 & 288 & 157782 \\
\hline Csongrád & 834 & 510794 & 356 & 230728 \\
\hline Southern Great Plain & 2198 & 1254355 & 946 & 564047 \\
\hline Baranya & 684 & 381740 & 303 & 171802 \\
\hline Somogy & 274 & 176841 & 121 & 82955 \\
\hline Tolna & 450 & 333549 & 191 & 141314 \\
\hline Southern Transdanubia & 1408 & 892130 & 615 & 396071 \\
\hline Hajdú-Bihar & 984 & 524544 & 402 & 219237 \\
\hline Jász-Nagykun-Szolnok & 924 & 719934 & 385 & 300564 \\
\hline Szabolcs-Szatmár-Bereg & 516 & 210557 & 197 & 77673 \\
\hline Northern Great Plain & 2424 & 1455035 & 984 & 597474 \\
\hline
\end{tabular}


(Continuation)

\begin{tabular}{|c|c|c|c|c|}
\hline \multirow[b]{2}{*}{ Region/county } & \multicolumn{2}{|c|}{ Person in the household } & \multicolumn{2}{|c|}{ Household } \\
\hline & Respondent & $\begin{array}{l}\text { Respondent } \\
\text { (weighted) }\end{array}$ & Respondent & $\begin{array}{l}\text { Respondent } \\
\text { (weighted) }\end{array}$ \\
\hline Borsod-Abaúj-Zemplén & 1106 & 775287 & 458 & 308310 \\
\hline Heves & 504 & 279146 & 221 & 116957 \\
\hline Nógrád & 215 & 101620 & 89 & 39263 \\
\hline Northern Hungary & 1825 & 1156053 & 768 & 464530 \\
\hline Fejér & 745 & 489883 & 310 & 200446 \\
\hline Komárom-Esztergom & 383 & 259638 & 167 & 116764 \\
\hline Veszprém & 602 & 306275 & 258 & 129949 \\
\hline Central Transdanubia & 1730 & 1055796 & 735 & 447159 \\
\hline Budapest & 2243 & 1698143 & 1028 & 798636 \\
\hline Pest & 1362 & 1211560 & 538 & 464389 \\
\hline Central Hungary & 3605 & 2909703 & 1566 & 1263025 \\
\hline Győr-Moson-Sopron & 773 & 526353 & 315 & 209322 \\
\hline Vas & 362 & 273336 & 143 & 105122 \\
\hline Zala & 298 & 174006 & 135 & 80921 \\
\hline Western Transdanubia & 1433 & 973695 & 593 & 395365 \\
\hline Total & 14623 & 9696767 & 6207 & 4127671 \\
\hline
\end{tabular}

Source: Own calculations. 